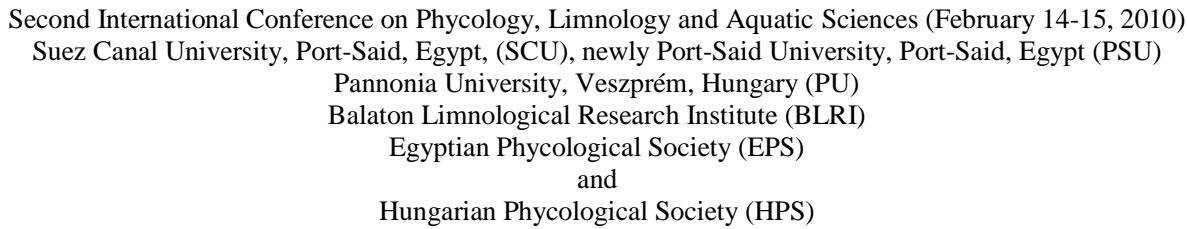

\title{
APPLICATION OF DRIED GREEN ALGAE TO REMOVE HEAVY METAL IONS FROM INDUSTRIAL WASTEWATER
}

\author{
Wael M. Ibrahim \\ Botany Department, Faculty of Science, Fayoum University \\ Fayoum, Egypt.
}

\begin{abstract}
Biosorption could be an effective process for the removal of toxic heavy metal ions from wastewater. In this study, the powder of three different species of marine green algae namely; Caulerpa racemosa, Enteromorpha intestinalis and Ulva lactuca were used to build up three types of fixed-bed columns for removal of heavy metal ions $\mathrm{Cd}^{2+}, \mathrm{Pb}^{2+}$, $\mathrm{Cu}^{2+}, \mathrm{Co}^{2+}, \mathrm{Zn}^{2+}, \mathrm{Mn}^{2+}, \mathrm{Ni}^{2+}, \mathrm{Fe}^{2+}$ and $\mathrm{Cr}^{3+}$ from three chemical industrial effluents. The C. racemosa column was relatively more efficient to remove metal ions from the different effluent samples followed by $U$. lactuca and E. intestinalis with mean metal ion bioremoval efficiencies of $83 \%, 80 \%$ and $76 \%$ respectively. Toxicity assessment test using Pseudokirchneriella subcapitata showed that, the biological treated effluents with algal columns reduced its toxicity as $\mathrm{EC}_{50}$ values were very high significantly increased from $6 \%$ to $98 \%$. This study verifies the possibility of using dried marine green algae as valuable material for the removal of toxic heavy metals from industrial wastewater.
\end{abstract}

Keywords: Caulerpa racemosa, Enteromorpha intestinalis, Ulva lactuca, Heavy metals, Industrial wastewater.

\section{Introduction}

The release of different pollutants into environment has increased noticeably as a result of industrialization, and thereby lowered the quality of the environment to alarming levels (Sari and Tuzen, 2008). Heavy metal pollution has become a more serious environmental problem in the last several decades as a result of its toxicity and insusceptibility to the environment. In addition to their toxic effects even at low concentrations, heavy metals can accumulate throughout the food chain, which leads to serious ecological and health hazards as a result of their solubility and mobility (Kumar et al., 2006).

Numerous conventional methods such as ion exchange, precipitation, ultrafiltration, reverse osmosis and electro dialysis have been used for the removal 
of heavy metal ions from aqueous solution (Liu et al., 2009). These conventional techniques can reduce metal ions, but they do not appear to be highly effective when applied to low strength wastes with heavy metal ion concentrations less than 100 ppm (Wang and Chen, 2009). The most popular of these technologies is activated carbon adsorption and widely used but it is expensive. Therefore, there is a growing interest in using low-cost, effective and easily available materials for the removal of metal ions (Ozer et al., 2008). Recently, bioremoval has emerged as an alternative treatment technology for heavy metals. There have been a number of reports stating the success of such technology (Pagnanelli $\boldsymbol{e t}$ al., 2001). To ensure the applicability of this technology, more works are still needed for the removal of a mixture of heavy metals at various operating conditions (Apiratikul and Pavasant, 2006).

Bioremoval has been studied in various types of biomass including marine algae (Liu et al., 2009), bacteria (Ozdemir et al., 2009) and fungi (Zafar et al., 2007). Marine algae offer advantages for bioremoval because their macroscopic structures offer a convenient basis for the production of biosorbent particles suitable for sorption process applications (Vieira and Volesky, 2000). Although there have been a number of studies on the use of brown algae for heavy metal removal, limited studies have been directed towards the use of green marine algae for this purpose. The green marine algae could be used live or dead. However, non-living biomass is not affected by the toxicity of metal ions and the adsorbed metals could be easily recovered from the biomass by many chemical and physical methods, leading to repeated use of the biomass and better process economy (Abu Al-Rub et al., 2004).

The principal objective of the present study was to explore the feasibility of using the dried green algae Caulerpa racemosa, Enteromorpha intestinalis and Ulva lactuca for removal of toxic heavy metals from industrial effluents through continuous system.

\section{Materials and Methods}

\section{Preparation of algal powder:}

The green marine algae Caulerpa racemosa (J. Agardh), Enteromorpha intestinalis (Linnaeus) and Ulva lactuca (Linnaeus) were collected in May and June 2008 from Abo-Quir Bay, Alexandria, Egypt. The collected algae were washed with seawater, tap water, and then deionized water several times to remove impurities. The washing process was continued till the wash water contains no dirt. The washed algae were then completely air dried for 10 days. The dried algae were then cut into small pieces and were powdered using domestic mixer. The powdered materials were sieved to obtain $1-2 \mathrm{~mm}$ particles then directly used as adsorbents. 


\section{Sampling of industrial effluent:}

Three industrial effluents belong to different industries; Talkha for Chemical Fertilizers Factory, Kafr El-Zayaat for Salt and Soda Factory and ElFayoum for Chemical Production Company were chosen to investigate the efficiency of algal columns to remove heavy metal ions. Composite effluent samples were collected, at working hours of the factories, in polyethylene containers from their outfalls. Effluent samples were thoroughly mixed; six liters were filtered through GF/C Whatman glass filters. The first one liter filtrate was discarded and five liters were stored at $4^{\circ} \mathrm{C}$ in dark to be used for chemical and toxicity assessment analysis. The hydrogen ion activity of the filtered industrial effluents was adjusted at the $\mathrm{pH} 6.0$ (Optimum $\mathrm{pH}$ for heavy metal removal; Azab et al., 2008) by using $0.1 \mathrm{~N}$ nitric acid or sodium hydroxide solutions. $\mathrm{pH}$ adjusted effluents were passed through the different types of algal columns.

\section{Column experiments:}

Continuous-flow removal experiments were conducted in a laboratoryscale glass column with an internal diameter of $2.0 \mathrm{~cm}$ and $35 \mathrm{~cm}$ in length (Figure 1). Two plastic sieves both with pore size of $0.2 \mathrm{~mm}$ were installed at the top and bottom of this column. Individual columns were packed with $5.0 \mathrm{~g}$ of individual algal powders. The $\mathrm{pH}$ adjusted effluent was pumped up flow through the bed using a peristaltic pump connected at the bottom of the column. Experiments were carried out at flow rate $15 \mathrm{ml} \min ^{-1}$ (Lodeiro et al., 2006). Samples of the biologically treated effluents were filtered through GF/C Whatman glass filters, in order to separate the dissolved fraction from possible suspension material that may influence the heavy metal measurements. The filtrate was subjected for toxicity assessment and metal ion analysis.

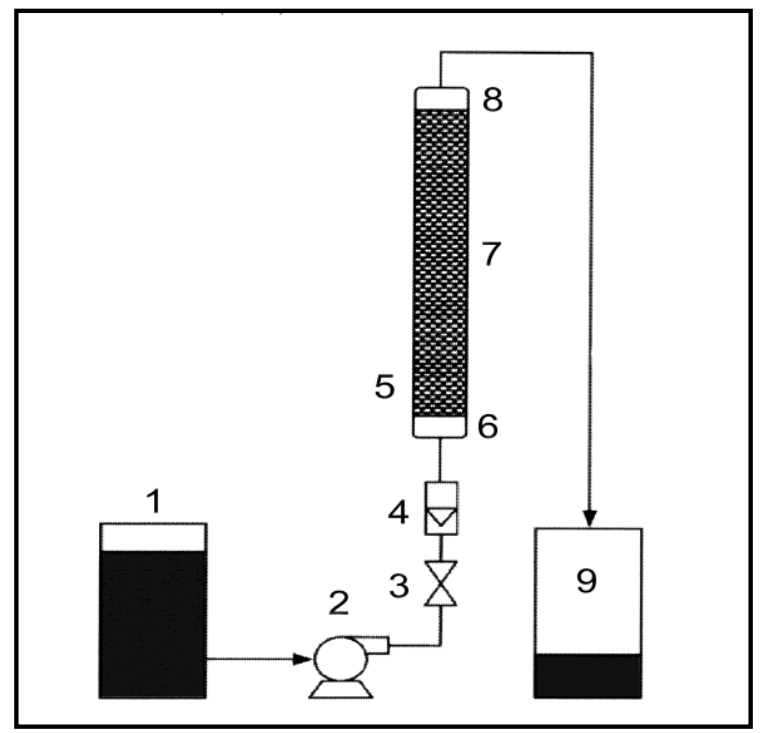

Figure (1): Experimental arrangement of the removal packed bed column.

(1) $\mathrm{pH}$ adjusted effluent

(2) Peristaltic pump

(3) Valve

(4) Flow meter

(5) Column

(6) Bottom sieve

(7) Packed algal powder

(8) Top sieve

(9) Algal treated effluent 


\section{Determination of heavy metals:}

The analyses of heavy metals in raw and biological treated effluents were measured as described by APHA (1989). Acidified filtered samples were analyzed for metal concentrations using Perkin-Elmer atomic absorption spectrophotometer (Model 2380). The metal removal efficiency of algal powder was calculated from the following equation.

$$
\% \text { of metal removal }=\left[\left(\mathrm{C}_{\mathrm{i}}-\mathrm{C}_{\mathrm{f}}\right) / \mathrm{C}_{\mathrm{i}}\right] \times 100
$$

Where: $C_{i}$ and $C_{f}$ are the initial and final metal ion concentrations $\left(\mathrm{mgl}^{-1}\right)$, respectively.

\section{Toxicity assessment of untreated and treated industrial effluents:}

The method described by Koukal $\boldsymbol{e t}$ al. (2003) was used to carry out toxicity test of GF/C filtered industrial effluent; $\mathrm{pH}$ adjusted effluent and biologically treated effluent. Growth inhibition test with Pseudokirchneriella subcapitata (NIVA-CHL1) (formerly known as Selenastrum capricornutum), was performed in algal medium according to the OECD guideline for testing of chemicals No. 201 (OECD, 2006). The initial algal density of $5 \times 10^{6}$ cells $1^{-1}$ were incubated for five days at $23 \pm 1^{\circ} \mathrm{C}$ under continuous illumination of $40 \mu \mathrm{Em}^{-2} \mathrm{~s}^{-1}$ provided by cool white fluorescent tubes. Cell counts were determined at the end of incubation period using a standard haemocytometer. $\mathrm{EC}_{50}$ and $\mathrm{SC}_{20}$ express the minimum effluent concentrations inhibiting and stimulating the algal growth by $50 \%$ and $20 \%$ respectively.

\section{Statistical analyses:}

Data were presented as mean replicates from three runs and were analyzed statistically using Student's $t$-test for independent samples. Statements of significant differences were based on accepting $\mathrm{P} \leq 0.05$ according to SPSS (1999).

\section{Results}

Some chemical properties of the three industrial effluents are demonstrated in (Table 1). The effluent of El-Fayoum for Chemical Production Company and Kafr-Ezayyat for Salt and Soda Factory were acidic with $\mathrm{pH}$ value of $5.43 \pm 0.2$ and $3.92 \pm 0.2$, respectively. Talkha for Chemical Fertilizers Factory effluent was alkaline with $\mathrm{pH}$ value of $9.86 \pm 0.2$. Concentrations of the heavy metal ions varied slightly from one effluent to another. The concentrations of different metal ions of El-Fayoum for Chemical Production Company ranged from $0.48 \pm 0.1 \mathrm{mgl}^{-1}$ to $1.57 \pm 0.2 \mathrm{mgl}^{-1}$ while those of Kafr-Ezayaat Salt and Soda Factory ranged between $0.47 \pm 0.1 \mathrm{mgl}^{-1}$ and $2.71 \pm 0.2 \mathrm{mgl}^{-1}$. The concentration of metal ions of Talkha for Chemical Fertilizers Factory varied from $0.48 \pm 0.1 \mathrm{mgl}^{-1}$ to $2.54 \pm 0.2 \mathrm{mgl}^{-1}$. 
Table (1): PH values and heavy metal concentrations $\left(\mathrm{mgl}^{-1}\right)$ of the investigated raw industrial effluents.

\begin{tabular}{cccc}
\hline Effluent & $\begin{array}{l}\text { El-Fayoum for Chemical } \\
\text { Production Company }\end{array}$ & $\begin{array}{l}\text { Kafr-Ezayyat for Salt } \\
\text { and Soda Factory }\end{array}$ & $\begin{array}{c}\text { Talkha for Chemical } \\
\text { Fertilizers Factory }\end{array}$ \\
\hline $\mathbf{p H}$ & $5.43 \pm 0.2$ & $3.92 \pm 0.2$ & $9.86 \pm 0.2$ \\
$\mathbf{C d}$ & $0.97 \pm 0.1$ & $0.78 \pm 0.1$ & $0.66 \pm 0.1$ \\
$\mathbf{C o}$ & $1.21 \pm 0.1$ & $0.51 \pm 0.1$ & $0.68 \pm 0.1$ \\
$\mathbf{C r}$ & $0.53 \pm 0.1$ & $0.47 \pm 0.1$ & $0.83 \pm 0.12$ \\
$\mathbf{C u}$ & $0.54 \pm 0.1$ & $0.74 \pm 0.1$ & $0.95 \pm 0.14$ \\
$\mathbf{F e}$ & $1.66 \pm 0.2$ & $2.71 \pm 0.2$ & $2.54 \pm 0.2$ \\
$\mathbf{M n}$ & $0.48 \pm 0.1$ & $0.63 \pm 0.1$ & $0.88 \pm 0.1$ \\
$\mathbf{N i}$ & $1.57 \pm 0.2$ & $0.56 \pm 0.1$ & $0.55 \pm 0.1$ \\
$\mathbf{P b}$ & $0.79 \pm 0.15$ & $0.88 \pm 0.15$ & $0.48 \pm 0.1$ \\
$\mathbf{Z n}$ & $0.64 \pm 0.1$ & $0.95 \pm 0.1$ & $0.75 \pm 0.1$ \\
\hline
\end{tabular}

Values are expressed as mean \pm standard error of three replicates.

The efficiency of algal columns to remove metal ions from industrial effluents displayed obvious variations that were mainly dependent on algal column, metal ion and the effluent type. The efficiency of algal column to remove different metal ions ranged between $49 \%$ to $98 \%$ from El-Fayoum for Chemical Production Company effluent (Figure 2), 34\% to 98\% from Kafr-Ezayyat for Salt and Soda Factory effluent (Figure 3 ) and $43 \%$ to $98 \%$ from Talkha for Chemical Fertilizers Factory effluent (Figure 4) with complete removal of highly toxic metal ions such as $\mathrm{Cd}, \mathrm{Cu}, \mathrm{Cr}, \mathrm{Mn}, \mathrm{Ni}$ and $\mathrm{Zn}$ from the three industrial effluents. In general, the $C$. racemosa column was relatively more efficient to remove metal ions from different effluent samples followed by U. lactuca and the lowest one was recorded for $E$. intestinalis with mean metal ion bioremoval efficiencies of $83 \%, 80 \%$ and $76 \%$ respectively (Figure 5).

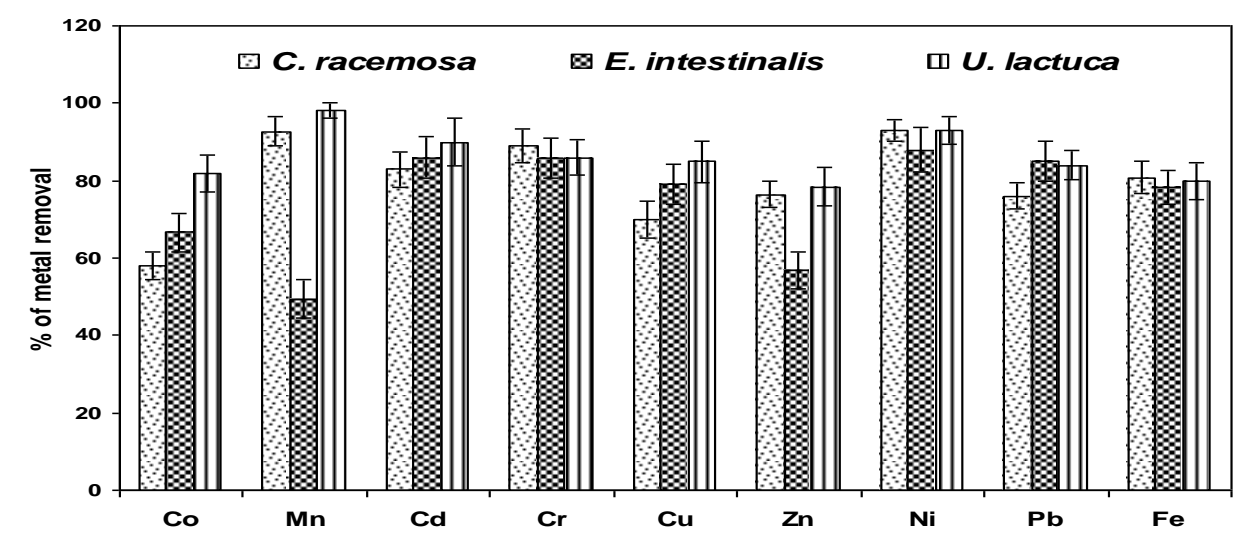

Figure (2): Percentage of bioremoval Heavy metal of different heavy metals from El Fayoum for Chemical Production company effluent. Error bars represent the standard errors of three replicates. 


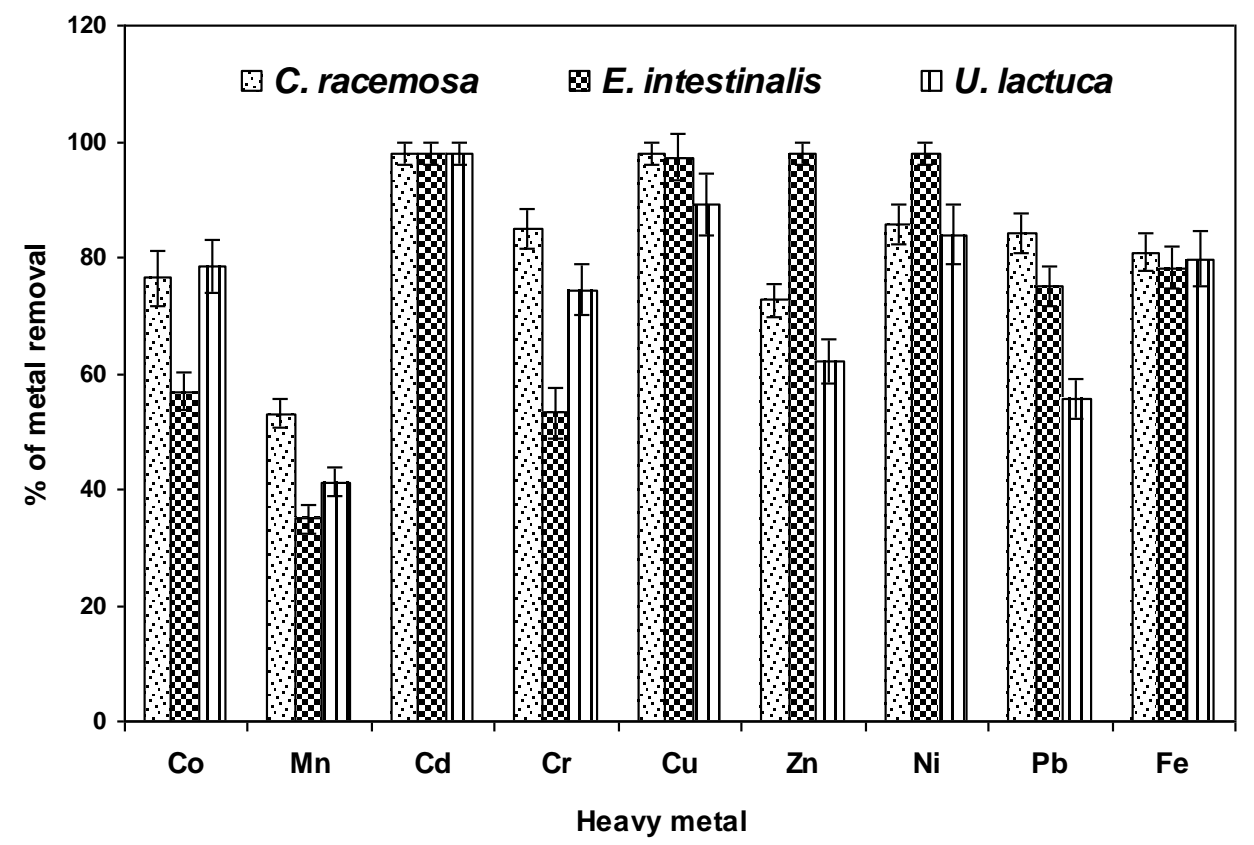

Figure (3): Percentage of bioremoval of different heavy metals from Kafr-Ezayyat for Salt and Soda Factory effluent. Error bars represent the standard errors of three replicates.

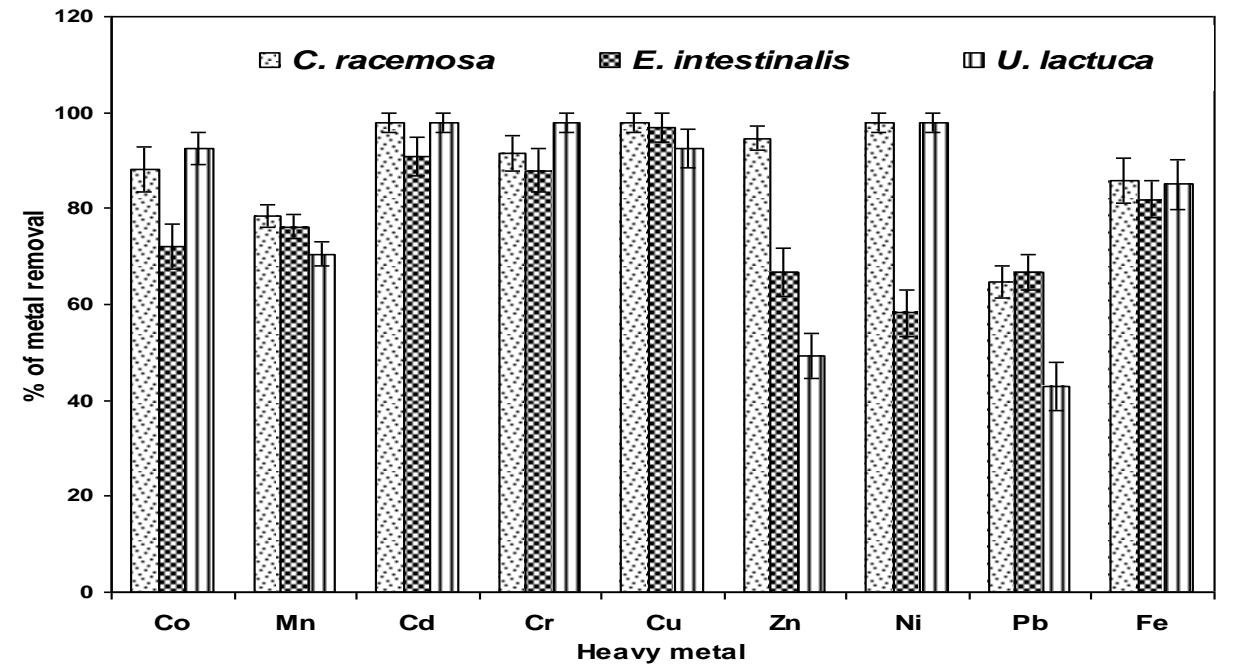

Figure (4): Percentage of bioremoval of different heavy metals from Talkha for Chemical Fertilizers Factory effluent. Error bars represent the standard errors of three replicates.

Egyptian J. of Phycol. Vol. 11, 2010 


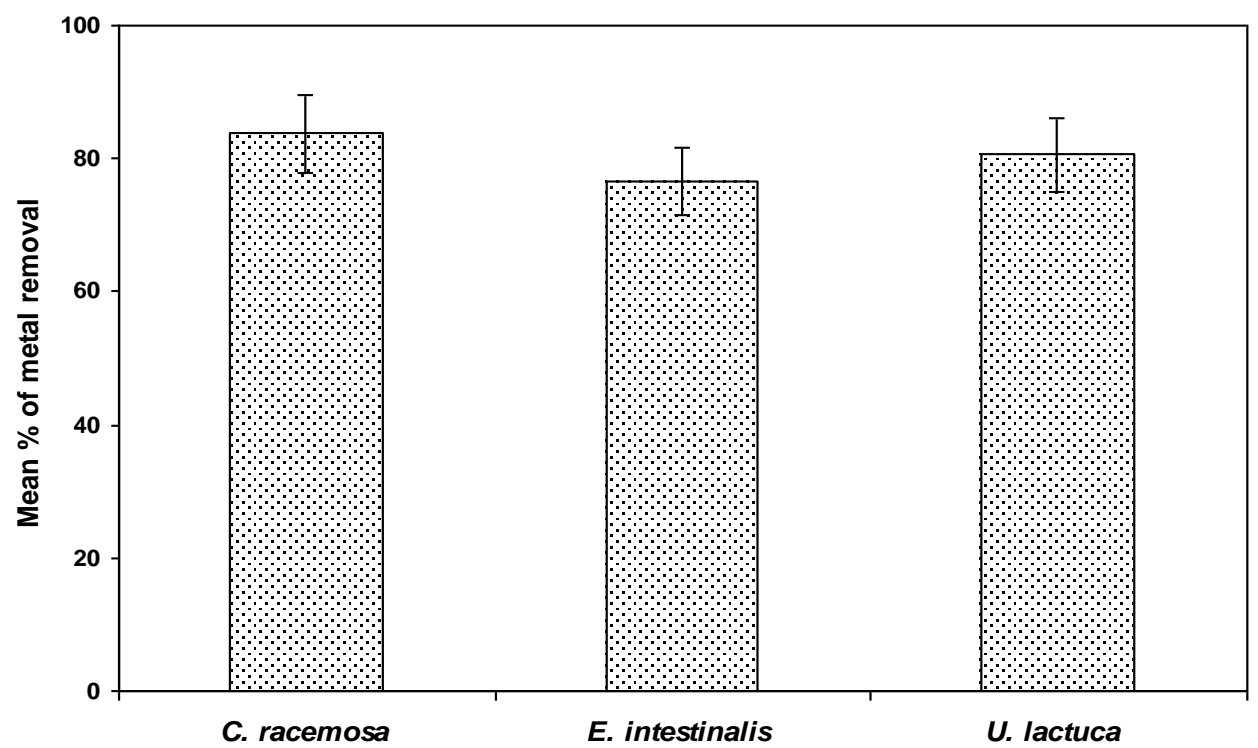

Figure (5): Mean efficiency of algal column to remove different heavy metals. Error bars represent the standard errors of three replicates.

Dose-response curves illustrating the relative growth (\% of the control count, considering control $=100 \%$ ) of Pseudokirchneriella subcapitata at different effluent doses are given in Figure (6). Values of $\mathrm{EC}_{50}$ were derived from doseresponse curve (Figure 7). It has been noted that the higher $\mathrm{EC}_{50}$ value, the lower the toxicity of a given effluent subsample.

The adjustment of industrial effluents $\mathrm{pH}$ to 6.0 brought about substantial decrease in their toxicities. In this context, the $\mathrm{EC}_{50}$ of raw and $\mathrm{pH}$ adjusted effluent of El-Fayoum for Chemical Production Company, Talkha for Chemical Fertilizers Factory and Kafr-Ezayyat for Salt and Soda Factory were increased significantly from $13 \%$ to $39 \%$, from $4 \%$ to $6 \%$ and from $9 \%$ to $28 \%$ respectively (Figure 7). Algal treated samples of Talkha for Chemical Fertilizers Factory and El-Fayoum for Chemical Production Company effluents induced marginal algal growth stimulation at very low concentration with $\mathrm{SC}_{20}$ ranged from $1 \%$ to $10 \%$. While biologically treated samples of Kafr-Ezayyat for Salt and Soda Factory effluent exhibited marked algal growth stimulation at higher concentration level with $\mathrm{SC}_{20}$ reached to $60 \%$ (Figure 6).

Biological treatment of effluent samples with different algal columns decrease the effluent toxicity by increasing its $\mathrm{EC}_{50}$ value. The data (Figure 7) reveal that the $\mathrm{EC}_{50}$ of algal treated effluent of El-Fayoum for Chemical Production Company was very high significantly increased $(\mathrm{P} \leq 0.001)$ from $39 \%$ to $98 \%$. Algal treated effluent of Kafr-Ezayyat for Salt and Soda Factory showed a very high significant increase $(\mathrm{P} \leq 0.001)$ of $\mathrm{EC}_{50}$ from $28 \%$ to $98 \%$. Also, the 
$\mathrm{EC}_{50}$ of Talkha for Chemical Fertilizers Factory was very high significantly increased $(\mathrm{P} \leq 0.001)$ from $6 \%$ to $50 \%$.
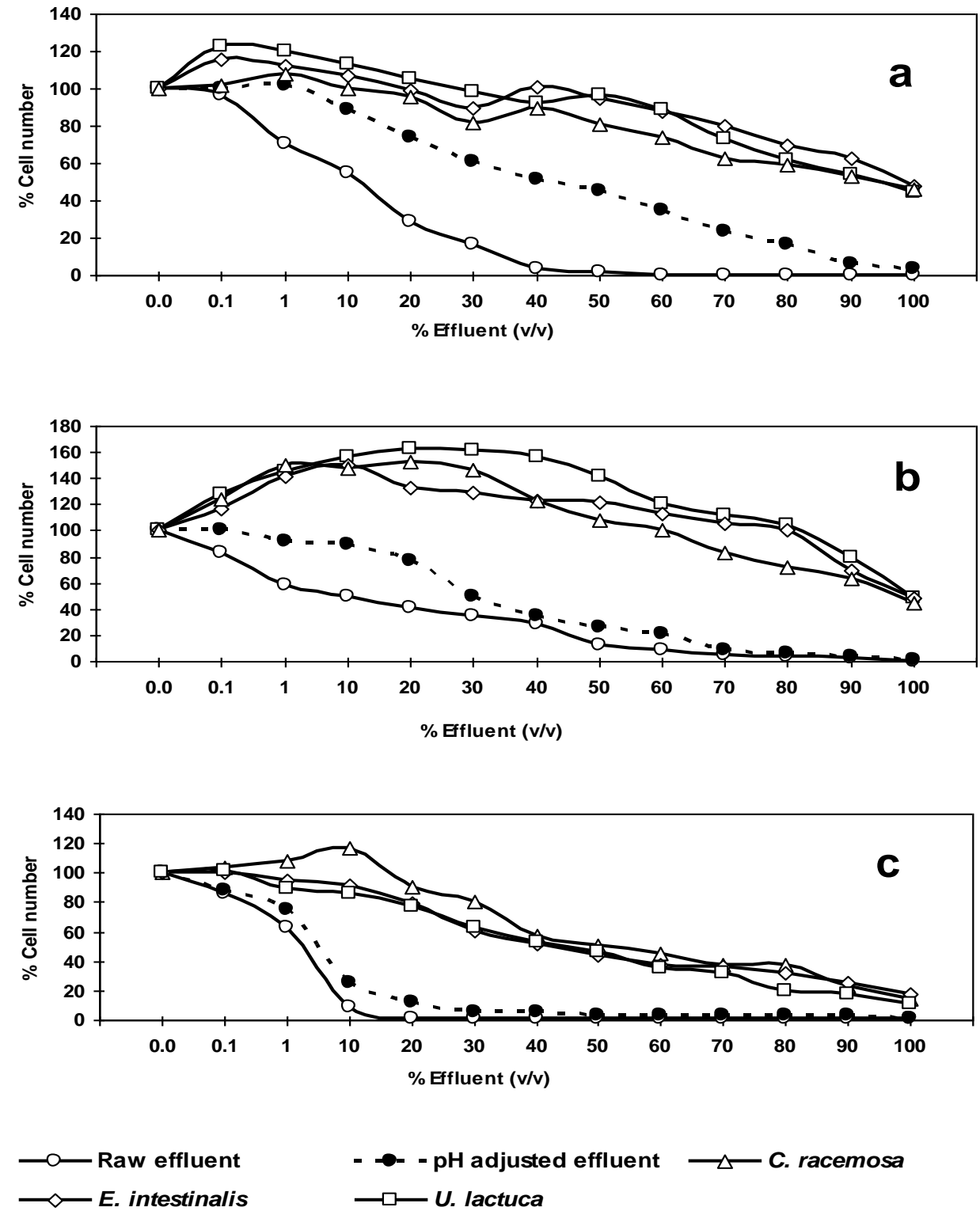

Figure (6): Dose-response curves of $\boldsymbol{P}$. subcapitata grown for 5 days at different concentration of effluents; (a) El-Fayoum for Chemical production Company, (b) Kafr El-Zayaat for Salt and Soda Factory and (c) Talkha for Chemical Fertilizers Factory. 


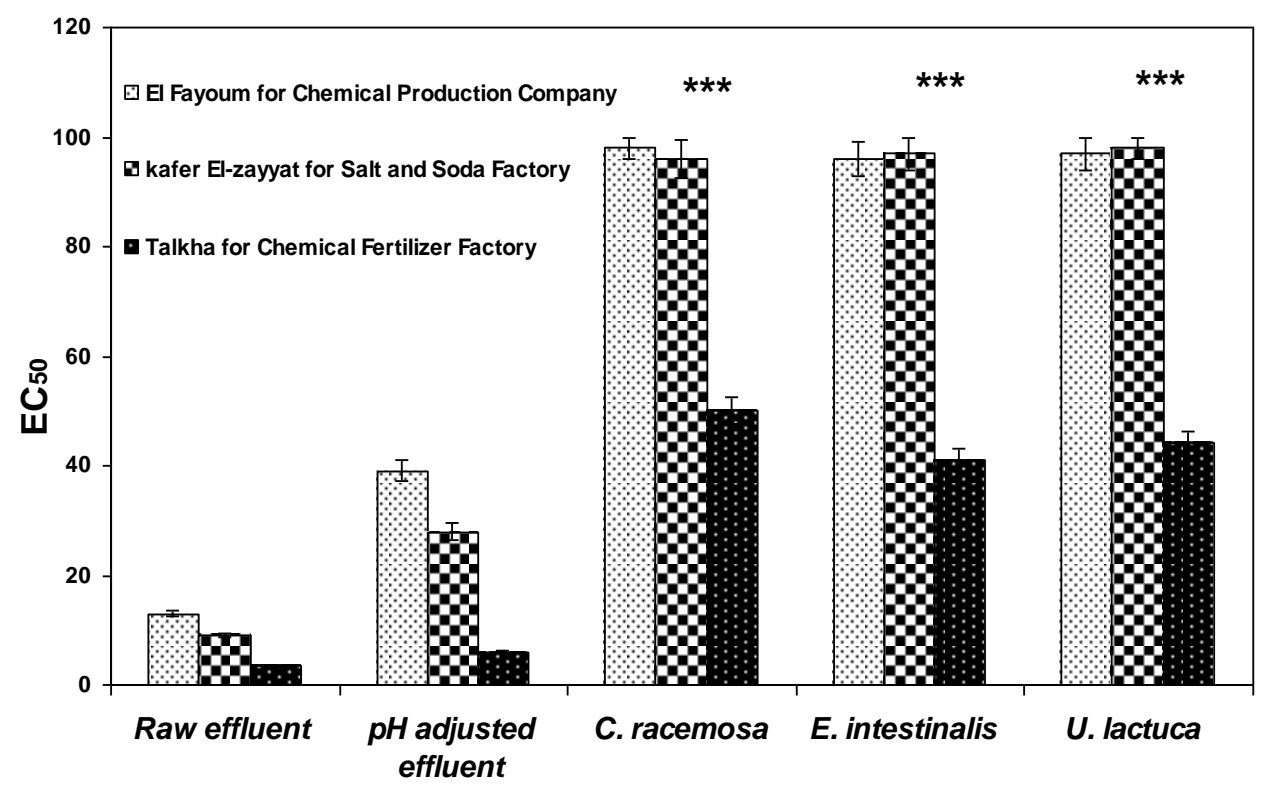

Figure (7): Efficiency of algal column to reduce toxicity of different industrial effluents.

*** Very high significant increase of algal treated effluent compared to $\mathbf{p H}$ adjusted. Error bars represent the standard errors of three replicates.

\section{Discussion}

Concentration of heavy metal ions in the industrial effluents varied from one effluent to another and in general ranged from $0.47 \pm 0.1 \mathrm{mgl}^{-1}$ to $2.71 \pm 0.2 \mathrm{mgl}^{-1}$ (Table 1). These results are in agreement with Sari and Tuzen (2008), Lesmana et al. (2009) and Ozer et al. (2009) who reported that, the primary sources of heavy metal ions into environment are the wastewater of several industrial processes such as; electroplating, metal finishing, chemical fertilizers, tanning, chemical manufacturing, mining and battery manufacturing.

The dried green algal columns of C. racemosa, E. intestinalis and $U$. lactuca were capable to remove different heavy metals from industrial effluents with mean metal ion bioremoval efficiencies ranged from 76\% to $83 \%$ (Figure 5). These results are in accordance with El-Sikaily et al. (2007) who used marine dried green alga Ulva lactuca for the removal of toxic chromium ions from aqueous solution and wastewater. They found that, the maximum efficiency of removal was $92 \%$. Ulva lactuca has a sheet-like thallus with two cells thick; resulting in a relatively high surface area of structurally uniform which can explain its high efficiency to remove metal ions (Turner et al., 2007). Kumar $\boldsymbol{e t}$ al. (2006) studied the removal of zinc and copper from aqueous solution by Ulva fasciata. They found that the removal of heavy metal ions by $U$. fasciata were about $74 \%$ and $94 \%$, respectively. 
The high efficiency of $C$. racemosa column to remove metal ions from industrial effluents may be due to the presence of various functional groups on the surface of dried algal biomass which can act as binding sites for heavy metals. This explanation is in agreement with Pavasant et al. (2006) who found several functional groups on the surface of dried Caulerpa sp. such as carboxylic acid, amine, amide, amino, sulfonyl, and sulfonate groups. Apiratikul and Pavasant (2008) investigated the biosorption of the three heavy metal ions $\left(\mathrm{Cu}^{+2}, \mathrm{Cd}^{+2}\right.$ and $\mathrm{Pb}^{+2}$ ) both in batch and column systems with dried biomass of Caulerpa lentillifera. They found that about $83 \%$ of heavy metal ions could be adsorbed on free binding sites in the biomass.

The success of dried green algal columns in removing toxic heavy metal ions from different industrial effluents, reducing the effluent toxicity and improving the growth of standard test alga $P$. subcapitata, especially at lower concentrations of biologically treated effluents. This can be easily noticed from the $\mathrm{SC}_{20}$ and $\mathrm{EC}_{50}$ of treated effluent samples (Figures 6-7).

A strong evidence to that mentioned before concerning the toxic effect of different heavy metal ions to the standard test alga (Figures 6-7) comes from the work of Koukal $\boldsymbol{e t}$ al. (2003) who reported that, the photosynthetic activity of $P$. subcapitata in the presence of $\mathrm{Cd}^{+2}$ and $\mathrm{Zn}^{+2}$ showed a progressive decrease with increasing metal concentration. The $\mathrm{EC}_{50}$ were found at concentrations of $200 \mu \mathrm{gl}^{-1}$ and $390 \mu \mathrm{ul}^{-1}$, respectively. Aruoja et al. (2009) determined toxicities of $\mathrm{Zn}^{+2}$, $\mathrm{Cu}^{+2}$ and $\mathrm{Ti}^{+4}$ to $P$. subcapitata using OECD 201 algal growth inhibition test. They found that, the metal ions of $\mathrm{Zn}^{+2}$ were most toxic followed by $\mathrm{Cu}^{+2}$ and $\mathrm{Ti}^{+4}$. The $\mathrm{EC}_{50}$ were $0.04 \mathrm{mgl}^{-1}, 11.55 \mathrm{mgl}^{-1}$ and $35.9 \mathrm{mgl}^{-1}$, respectively. Moreover, Lavoie et al. (2009) reported that, P. subcapitata was more sensitive to $\mathrm{Cd}^{+2}$ exposure with an $\mathrm{EC}_{50}$ of $273 \mu \mathrm{gl}^{-1}$.

The results of this study introduce a good hope to use the dried green algal columns of $C$. racemosa, E. intestinalis and $U$. lactuca for removal of heavy metal ions from different industrial effluents. The high biosorption efficiency and low cost makes these algal columns as an effective, cheap and alternative technique for processing wastewater containing heavy metals.

\section{References}

Abu Al-Rub, F.A.; El-Naas, M.H.; Benyahia, F. and Ashour, I. (2004). Biosorption of nickel on blank alginate beads, free and immobilized algal cells. Proc. Biochem., 39: 1767-1773.

APHA (1989). Standard methods for the examination of water and wastewater, $17^{\text {th }}$ ed. American Public Health Association, New York, 626 pp.

Apiratikul, R. and Pavasant, P. (2006). Sorption isotherm model for binary component sorption of copper, cadmium, and lead ions using dried green macroalga, Caulerpa lentillifera. Chem. Eng. J., 119:135-145. 
Apiratikul, R. and Pavasant, P. (2008). Batch and column studies of biosorption of heavy metals by Caulerpa lentillifera. Biores. Technol., 99: 2766-2777.

Aruoja, V.; Dubourguiera, H.; Kasemetsa, K. and Kahru, A. (2009). Toxicity of nanoparticles of $\mathrm{CuO}, \mathrm{ZnO}$ and $\mathrm{TiO}_{2}$ to microalgae Pseudokirchneriella subcapitata. Sci. Tot. Environ., 407:1461-1468.

Azab, Y.A.; Ibrahim, W. M. and Hussien, M. (2008). Development of algal biofilters for the treatment of heavy metal pollution from industrial wastewater. Catrina, 3 (2):49-67.

El-Sikaily, A.; El Nemr, A.; Khaled, A. and Abdelwehab O. (2007). Removal of toxic chromium from wastewater using green alga Ulva lactuca and its activated carbon. J. Hazard. Mater, 148, 216-228.

Koukal, B.; Gueguen, C.; Pardos, M. and Dominik J. (2003). Influence of humic substances on the toxic effects of cadmium and zinc to the green alga Pseudokirchneriella subcapitata. Chemosphere, 53:953-961.

Kumar, Y.P.; King, P. and Prasad V.S.R.K. (2006). Comparison for adsorption modeling of copper and zinc from aqueous solution by Ulva fasciata. J. Hazard. Mater, 137:1246-1251.

Lavoie, M.; Le Faucheur, S.; Fortin, C. and Peter, G.C. (2009). Cadmium detoxification strategies in two phytoplankton species: Metal binding by newly synthesized thiolated peptides and metal sequestration in granules. Aquat. Toxicol., 92:65-75.

Lesmana, S.O.; Febriana, N.; Soetaredjo, F. E.; Sunarso, J. and Ismadji, S. (2009). Studies on potential applications of biomass for the separation of heavy metals from water and wastewater. Biochem. Eng. J., 44:19-41.

Liu, Y.; Cao, Q.; Luo, F. and Chen, J. (2009). Biosorption of $\mathrm{Cd}^{2+}, \mathrm{Cu}^{2+,} \mathrm{Ni}^{2+}$ and $\mathrm{Zn}^{2+}$ ions from aqueous solutions by pretreated biomass of brown algae. J. Hazard. Mater, 163:931-938.

Lodeiro, P.; Herrero, R. and Sastre de Vicente, M.E. (2006). The use of protonated Sargassum muticum as biosorbent for cadmium removal in a fixed-bed column. J. Hazard. Mater, 137:244-253.

Organization for Economic Co-operation and Development (OECD) (2006). OECD Guideline for Testing of Chemicals Test Guideline 201 Freshwater Alga and Cyanobacteria, Growth Inhibition Test.

Ozdemir, S.; Kilinc, E.; Poli, A.; Nicolaus, B. and Guven, K. (2009). Biosorption of $\mathrm{Cd}, \mathrm{Cu}, \mathrm{Ni}, \mathrm{Mn}$ and $\mathrm{Zn}$ from aqueous solutions by thermophilic bacteria, Geobacillus toebii sub.sp. decanicus and Geobacillus thermoleovorans sub. sp. stromboliensis: Equilibrium, kinetic and thermodynamic studies. Chem. Eng. J., 152:195-206.

Ozer, A.; Gurbuz, G.; Calimli, A. and Korbahti, B.K. (2008). Investigation of nickel(II) biosorption on Enteromorpha prolifera: Optimization using response surface analysis. J. Hazard. Mater, 152: 778-788.

Ozer, A.; Gürbüz, G.; Calimli, A. and Krrbahti, B.K. (2009). Biosorption of copper(II) ions on Enteromorpha prolifera: Application of response surface methodology (RSM). Chem. Eng. J., 146:377-387. 
Pagnanelli, F.; Trifonia, M.; Beolchini, F. ; Espositoc, A. ; Toroa, L. and Veglio, F. (2001). Equilibrium biosorption studies in single and multi-metal systems. Proc. Biochem., 37:115-124.

Pavasant, P.; Apiratikul, R.; Sungkhum, V.; Suthiparinyanont, P.; Wattanachira, S. and Marhaba, T. F. (2006). Biosorption of $\mathrm{Cu}^{2+}, \mathrm{Cd}^{2+}$, $\mathrm{Pb}^{2+}$, and $\mathrm{Zn}^{2+}$ using dried marine green macroalga Caulerpa lentillifera. Biores. Technol., 97:2321-2329.

Sari, A. and Tuzen M. (2008). Biosorption of $\mathrm{Pb}(\mathrm{II})$ and $\mathrm{Cd}(\mathrm{II})$ from aqueous solution using green alga (Ulva lactuca) biomass. J. Hazard. Mater, 152:302308.

SPSS (1999). SPSS Base of 10 User's Guide. SPSS, Inc. Stanley, L.C., Ogden, K.L., 2003. Biosorption of copper (II) from chemical mechanical planarization wastewaters. J. Environ. Manage, 69:289-297.

Turner, A.; Lewis, M.S.; Brown, M.T. and Shams, L. (2007). Uptake of platinum group elements by the marine macroalga, Ulva lactuca. Marine Chem., 105: 275-280.

Vieira, R.H.S.F. and Volesky, B. (2000). Biosorption: a solution to pollution. Int. Microbiol., 3:17-24.

Wang, J. and Chen, C. (2009). Biosorbents for heavy metals removal and their future. Biotechnol. Advan., 27:195-226.

Zafar, S.; Aqil, F. and Ahmad, I. (2007). Metal tolerance and biosorption potential of filamentous fungi isolated from metal contaminated agricultural soil. Biores. Technol., 98:2557-2561.

$$
\begin{aligned}
& \text { الاستخدام التطبيقي للطحالب الخضراء الجافة في إزالة ايونات المعادن الثقيلة من } \\
& \text { مياه الصرف الصناعي. } \\
& \text { وائل ابراهيم } \\
& \text { قسم النبات - كلية العلوم- جامعة الفيوم }
\end{aligned}
$$

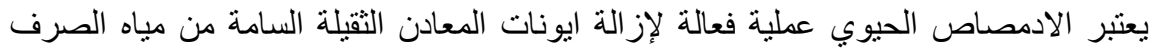

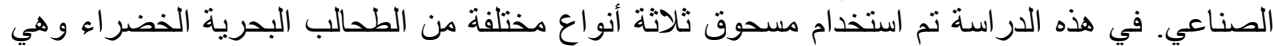

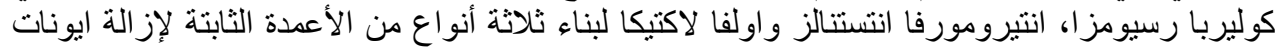

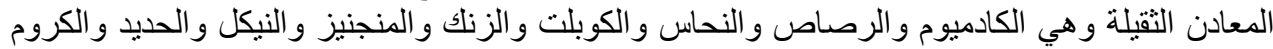

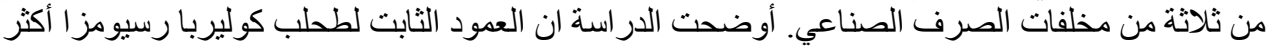

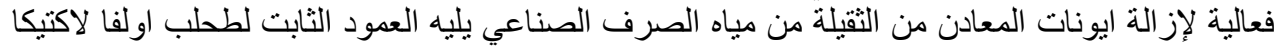

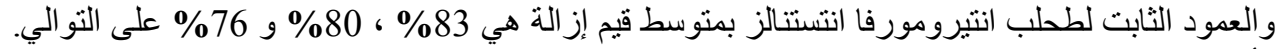

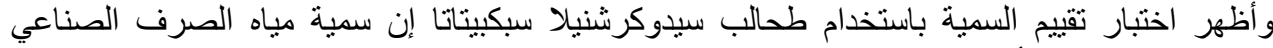

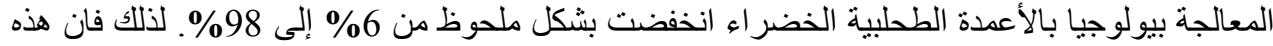

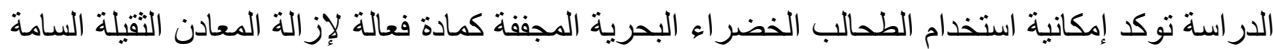

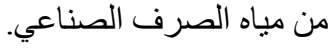

